\title{
SERUM CITRIC ACID AFTER INGESTION OF GLUCOSE IN NORMAL AND STARVED SUBJECTS
}

\author{
BY KNUD LUNDBAEK, VILLY POSBORG PETERSEN, AND \\ FRITZ SCHONHEYDER \\ (From the University Clinic of Internal Medicine, Aarhus Kommunehospital, and the Depart- \\ ment of Biochemistry, Aarhus University Medical School, Aarhus, Denmark)
}

(Received for publication October 10, 1949)

During starvation or carbohydrate deprivation certain changes take place in the metabolic pattern of animals and human beings, leading to "abnormalities" in carbohydrate metabolism. These changes reveal themselves in manifold ways: the glucose tolerance curve after carbohydrate deprivation is high and prolonged (1-4), and after severe starvation the $R Q$ response to administered glucose is low or absent (5). Glucose uptake by the isolated rat diaphragm has been shown to be reduced in animals maintained for some time on a carbohydrate-free diet (6). The rise in blood pyruvic acid after glucose is late and prolonged in fasted human subjects (7). In hepatectomized animals the amount of glucose necessary to prevent the blood sugar from falling is reduced, and the survival time without glucose is prolonged, if a carbohydrate-free diet has been given before the experiment $(8,9)$. The spontaneous carbohydrate intake is low in rats after a period on a carbohydratefree diet (10). The insulin content of the pancreas (11) and the blood sugar lowering effect of injected insulin (12) is reduced by carbohydrate deprivation. Recently it has been found that changes can be demonstrated on the enzymatic level. Muscle phosphorylase activity is increased, and the percentage of phosphorylase $a$ is higher than normal in rats having fasted for one to five days (13).

All these findings demonstrate that during carbohydrate deprivation profound changes are taking place in the hormonal and enzymatic pattern of carbohydrate metabolism, leading to the characteristic picture of starvation diabetes (14).

In a recent report Natelson, Pincus and Lugovoy showed that the level of serum citric acid decreases after ingestion of glucose by normal human subjects (15). It was therefore thought of interest to determine the variations in serum citric acid when glucose was given to subjects having been fasted for some time.

\section{PROCEDURE AND METHODS}

Normal students, ranging in age from 20 to 25 years, were fasted for a period of seven days. Water was given ad libitum and the subjects were allowed complete freedom as regards moving about or staying in bed. Weight, pulse rate, urine volume and ketonuria were determined daily. In some cases plasma bicarbonate was determined at frequent intervals.

At the end of the starvation period 70 grams of glucose were given orally. Blood glucose was determined before administration of glucose and at $\mathbf{3 0}$ minute intervals thereafter for three hours. Serum citric acid was determined prior to and at hourly intervals for the same three hours. In each case a similar test was performed in the normal state, either before the starvation period, or three to four weeks after, when normal weight has been regained.

All subjects were confined to bed during the test.

Blood glucose was determined by the Hagedorn method, and serum citric acid by the method of Thunberg as modified by Mårtensson (16).

\section{RESULTS}

A decrease in body weight from 4.8 to $7.2 \mathrm{~kg}$. (average $5.6 \mathrm{~kg}$.) was observed to occur during the experimental period. Ketonuria usually appeared on the second or third day of fasting. Plasma bicarbonate generally decreased by 4 to 6 m.eq. in the course of the week.

The results of the glucose administration are shown in Table I. It is evident that in the first 10 cases the glucose tolerance curve is higher and more prolonged after fasting than in the normal state. The serum citric acid shows a fall in most instances in the normal state. After starvation a decrease is found only in a few subjects. Usually no change or a small rise occurred. Figure 1 shows the changes in the serum citric acid levels in these 10 cases. The average values of these changes in the first, second and third hour after glucose administration are $-3.8,-4.6$ and -4.0 $\gamma / \mathrm{ml}$. in the normal state. After starvation the corresponding average values are $+1.7,+3.8$ and $+1: 1 \gamma / \mathrm{ml}$. The difference between these 
average values is statistically significant at every point of the curves $\left(t=3.65,3.19,4.43 ; t_{0.01}=\right.$ 2.88). The average of the zero values in the normal and post-starvation state are 32.1 and 33.7 $\gamma / \mathrm{ml}$. (no significant difference).

In the last two cases shown in Table I different results were obtained. The glucose tolerance curves after starvation were essentially normal, showing no significant change when compared with the curves obtained in the normal state. In these two cases no flattening occurred in the serum citric acid curve after starvation. In all other respects observed (general behaviour and activity, body weight, ketonuria, decrease in plasma bicarbonate) these subjects did not differ from the first 10 listed.

DISCUSSION

The results obtained confirm the findings of Natelson, Pincus, and Lugovoy (15) that the cit-

\begin{tabular}{|c|c|c|c|c|c|}
\hline & \multirow{2}{*}{$\begin{array}{c}\text { Hours } \\
\text { after } \\
\text { glucose }\end{array}$} & \multicolumn{2}{|c|}{ Normal } & \multicolumn{2}{|c|}{ After fasting } \\
\hline & & $\begin{array}{l}\text { Serum } \\
\text { citric } \\
\text { acid }\end{array}$ & $\begin{array}{c}\text { Blood } \\
\text { glucose }\end{array}$ & $\begin{array}{l}\text { Serum } \\
\text { citric } \\
\text { acid }\end{array}$ & $\begin{array}{c}\text { Blood } \\
\text { glucose }\end{array}$ \\
\hline 1. J. T. & $\begin{array}{l}0 \\
\frac{1}{2} \\
1 \\
2 \\
3\end{array}$ & $\begin{array}{c}\gamma / \mathrm{ml} . \\
32.5 \\
\\
30.8 \\
29.2 \\
25.0\end{array}$ & $\begin{array}{c}m g . \% \\
110 \\
181 \\
120 \\
110 \\
112\end{array}$ & $\begin{array}{c}\gamma / \mathrm{ml} . \\
33.0 \\
\\
35.0 \\
34.5 \\
37.5\end{array}$ & $\begin{array}{c}\boldsymbol{m g . \%} \\
55 \\
207 \\
176 \\
185 \\
135\end{array}$ \\
\hline 2. H. R. & $\begin{array}{l}0 \\
\frac{1}{2} \\
1 \\
2 \\
3\end{array}$ & $\begin{array}{l}33.5 \\
29.8 \\
32.1 \\
35.0\end{array}$ & $\begin{array}{r}90 \\
124 \\
90 \\
90 \\
70\end{array}$ & $\begin{array}{l}34.2 \\
34.7 \\
33.5 \\
35.4\end{array}$ & $\begin{array}{r}75 \\
176 \\
145 \\
217 \\
85\end{array}$ \\
\hline 3. E.T. & $\begin{array}{l}0 \\
\frac{1}{2} \\
1 \\
2 \\
3\end{array}$ & $\begin{array}{l}34.5 \\
30.2 \\
27.9 \\
29.9\end{array}$ & $\begin{array}{l}100 \\
161 \\
150 \\
130 \\
100\end{array}$ & $\begin{array}{l}38.0 \\
39.1 \\
35.5 \\
38.5\end{array}$ & $\begin{array}{r}90 \\
212 \\
212 \\
244 \\
242\end{array}$ \\
\hline 4. B. D. & $\begin{array}{l}0 \\
\frac{1}{2} \\
1 \\
2 \\
3\end{array}$ & $\begin{array}{l}31.0 \\
31.0 \\
31.8 \\
30.0\end{array}$ & $\begin{array}{r}95 \\
130 \\
128 \\
121 \\
90\end{array}$ & $\begin{array}{l}32.0 \\
34.5 \\
33.2 \\
33.8\end{array}$ & $\begin{array}{r}80 \\
156 \\
181 \\
233 \\
254\end{array}$ \\
\hline 5. J. A. & $\begin{array}{l}0 \\
1 \\
\frac{1}{2} \\
1 \\
2 \\
3\end{array}$ & $\begin{array}{l}47.1 \\
43.5 \\
39.0 \\
49.0\end{array}$ & $\begin{array}{r}75 \\
162 \\
111 \\
65 \\
75\end{array}$ & $\begin{array}{l}46.0 \\
44.5 \\
49.6 \\
50.3\end{array}$ & $\begin{array}{r}65 \\
140 \\
192 \\
210 \\
140\end{array}$ \\
\hline 6. A. H. & $\begin{array}{l}0 \\
\frac{1}{3} \\
1 \\
2 \\
3\end{array}$ & $\begin{array}{l}21.6 \\
\\
24.3 \\
19.5 \\
15.6\end{array}$ & $\begin{array}{r}91 \\
126 \\
96 \\
70 \\
82\end{array}$ & $\begin{array}{l}26.4 \\
26.7 \\
24.5 \\
25.2\end{array}$ & $\begin{array}{r}90 \\
143 \\
196 \\
220 \\
204\end{array}$ \\
\hline
\end{tabular}

TABLE I-Continued

\begin{tabular}{|c|c|c|c|c|c|}
\hline & \multirow{2}{*}{$\begin{array}{c}\text { Hours } \\
\text { after } \\
\text { glucose }\end{array}$} & \multicolumn{2}{|c|}{ Normal } & \multicolumn{2}{|c|}{ After fasting } \\
\hline & & $\begin{array}{l}\text { Serum } \\
\text { citric } \\
\text { acid }\end{array}$ & $\begin{array}{c}\text { Blood } \\
\text { glucose }\end{array}$ & $\begin{array}{l}\text { Serum } \\
\text { citric } \\
\text { acid }\end{array}$ & $\begin{array}{c}\text { Blood } \\
\text { glucose }\end{array}$ \\
\hline 7. S. T. & $\begin{array}{l}0 \\
\frac{1}{2} \\
1 \\
2 \\
3\end{array}$ & $\begin{array}{c}r / \mathrm{ml} . \\
36.1 \\
\\
27.5 \\
32.3 \\
32.3\end{array}$ & $\begin{array}{c}m g . \% \\
100 \\
139 \\
125 \\
95 \\
75\end{array}$ & $\begin{array}{c}\gamma / \mathrm{ml} . \\
29.3 \\
\\
31.5 \\
35.2 \\
38.6\end{array}$ & $\begin{array}{c}m g . \% \\
75 \\
140 \\
182 \\
182 \\
161\end{array}$ \\
\hline 8. L. R. & $\begin{array}{l}0 \\
\frac{1}{2} \\
1 \\
2 \\
3\end{array}$ & $\begin{array}{l}25.8 \\
21.0 \\
17.0 \\
13.0\end{array}$ & $\begin{array}{r}80 \\
135 \\
96 \\
74 \\
60\end{array}$ & $\begin{array}{l}31.0 \\
33.1 \\
33.3 \\
34.6\end{array}$ & $\begin{array}{l}100 \\
161 \\
172 \\
200 \\
100\end{array}$ \\
\hline 9. J. J. & $\begin{array}{l}0 \\
\frac{1}{2} \\
1 \\
2 \\
3\end{array}$ & $\begin{array}{l}21.8 \\
22.2 \\
22.2 \\
17.8\end{array}$ & $\begin{array}{r}80 \\
104 \\
116 \\
76 \\
62\end{array}$ & $\begin{array}{l}35.7 \\
37.2 \\
31.4 \\
38.2\end{array}$ & $\begin{array}{r}90 \\
130 \\
172 \\
201 \\
110\end{array}$ \\
\hline 10. B. S. & $\begin{array}{l}0 \\
\frac{1}{2} \\
1 \\
2 \\
3\end{array}$ & $\begin{array}{l}27.1 \\
19.6 \\
22.1 \\
15.8\end{array}$ & $\begin{array}{r}92 \\
163 \\
179 \\
120 \\
84\end{array}$ & $\begin{array}{l}24.6 \\
29.7 \\
27.9 \\
31.5\end{array}$ & $\begin{array}{r}70 \\
112 \\
176 \\
206 \\
128\end{array}$ \\
\hline 11. H. L. & $\begin{array}{l}0 \\
\frac{1}{2} \\
1 \\
2 \\
3\end{array}$ & $\begin{array}{l}27.5 \\
28.8 \\
27.1 \\
20.2\end{array}$ & $\begin{array}{r}83 \\
140 \\
118 \\
90 \\
76\end{array}$ & $\begin{array}{l}29.7 \\
25.8 \\
24.8 \\
23.7\end{array}$ & $\begin{array}{r}70 \\
106 \\
163 \\
114 \\
70\end{array}$ \\
\hline 12. B. M. & $\begin{array}{l}0 \\
\frac{1}{2} \\
1 \\
2 \\
3\end{array}$ & $\begin{array}{l}25.5 \\
17.7 \\
16.5 \\
15.3\end{array}$ & $\begin{array}{r}73 \\
190 \\
122 \\
84 \\
80\end{array}$ & $\begin{array}{l}24.4 \\
20.7 \\
19.0 \\
23.2\end{array}$ & $\begin{array}{r}64 \\
140 \\
192 \\
149 \\
80\end{array}$ \\
\hline
\end{tabular}

ric acid of the blood decreases when carbohydrate is given to normal human subjects. The relationship between glucose and citric acid metabolism is well established, but the actual cause of the fall in serum citric acid levels during absorption of carbohydrate is not understood. Natelson, Pincus,

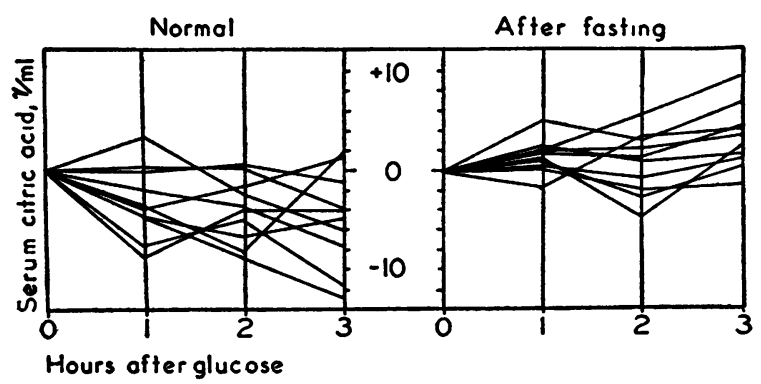

Fig. 1. Variations in Serum Citric Acid ( $/ / \mathrm{ml}$ ) after Ingestion of Glucose (Normal aNd Starved Subjects) 
and Lugovoy have suggested two possible explanations, either an inhibition of the citric acid formation, or an increased demand on the oxidative cycle during the sudden invasion of the blood stream by a large mass of glucose.

From the experiments reported here it appears that the normal fall of serum citric acid is lacking in most instances when glucose is given after a period of starvation. Actually a small increase was seen in most cases. It seems natural to combine the absence of a fall in the citric acid level with the other known abnormalities of carbohydrate metabolism in carbohydrate deprivation, in particular with the finding of a reduced glucose uptake by isolated muscle in animals maintained on a carbohydrate-free diet. To a certain extent the high level characteristic of glucose tolerance curves after starvation seems to represent a stasis of blood glucose, the migration of glucose from extracellular space to the tissue cells being lower than normal. If it is true that the normal fall of serum citric acid after glucose administration is caused by a withdrawal of serum citric acid by the cells for use in the oxidative cycle, it seems reasonable to assume that the lack of fall after starvation is an expression of the fact that less citric acid is needed for such a process. It has been shown recently (17) that epinephrine causes a rise in serum citric acid, a fact that might have some connection with the observed difference in citric acid response.

The finding of normal citric acid curves in the two subjects where the glucose tolerance curves were uninfluenced by starvation adds further support to the correlation between glucose and citric acid variations. It is well known that the effect of starvation or carbohydrate-free diet on the glucose tolerance curve shows a wide variation from one person to another, but essentially normal curves after starvation for one week is a rather surprising finding.

One point needs to be considered. During the starvation period a slight fall in plasma bicarbonate occurred, usually of about 4 to 6 m.eq. When glucose was given after the starvation period, we observed a rapid rise of plasma bicarbonate back to the initial values. It is known that the urinary excretion of citric acid is influenced by the $\mathrm{pH}$ of the blood, being higher in alkalosis, and lower in acidosis $(18,19)$. Moreover, a few experiments seem to indicate that the serum level of citric acid can be increased by administration of bicarbonate and decreased by acidifying substances $(20,21)$. In our experiments the starvation period with its slight acidosis did not in itself cause any significant change of serum citric acid. However, the rapid change in plasma bicarbonate during the post-starvation glucose test might perhaps be thought to influence the serum citric acid level. The $\mathrm{pH}$ of the blood was not determined in these experiments, but the possibility of the acid-baseequilibrium playing a part in the changes of citric acid observed after glucose ingestion was excluded by the findings in one of the two subjects whose citric acid curve was unaltered by starvation. In this case the slight fall of plasma bicarbonate in the starvation period, and the abrupt rise during re-feeding was just as pronounced as in the subjects who responded to starvation with the usual flattening of the citric acid curve.

As a practical consideration from the results obtained, it is emphasized that serum citric acid determinations for use in clinical work (liver diseases, etc.) must be made on serum obtained in the post-absorptive state.

\section{SUMMARY}

Experiments are reported on the effect of starvation on the fall of serum citric acid after glucose administration.

In 10 cases the well known high and prolonged glucose tolerance curve of starvation diabetes was obtained after one week's fasting. In these cases no fall was found in the average citric acid values; on the contrary a small increase often being encountered.

In two cases where no significant abnormality of the glucose tolerance curve was found after the starvation period, the serum citric acid decreased as in the normal state.

The lack of a fall of serum citric acid in starvation diabetes is thought to be connected with the low peripheral glucose utilization found in this state.

\section{BIBLIOGRAPHY}

1. Bang, I., Der Blutzucker. J. F. Bergmann, Wiesbaden, 1913.

2. du Vigneaud, V., and Karr, W. G., Carbohydrate utilization. I. Rate of disappearance of $d$-glucose from the blood. J. Biol. Chem., 1925, 66, 281. 
3. Malmros, H., A study of glycosuria, with special reference to interpretation of incidental finding of positive reduction test. Acta med. Scandinav., 1928, Suppl. 27.

4. Lundbaek, K., and Magnussen, G., Carbohydrate metabolism in insulin shock therapy. On the significance of the carbohydrate content of the diet to the glucose tolerance curve, insulin sensitivity and minimal coma-dose in insulin shock treatment of psychotics. Acta med. Scandinav., 1940, 105, 447.

5. Dann, M., and Chambers, W. H., Animal calorimetry ; the metabolism of glucose administered to the fasting dog. J. Biol. Chem., 1930, 89, 675.

6. Lundbaek, K., and Stevenson, J. A. F., The effect of previous carbohydrate deprivation on the carbohydrate metabolism of isolated muscle. Federation Proc., 1948, 7, 75.

7. Wollenberger, A., and Linton, M. A., Jr., The metabolism of glucose in starvation and water deprivation. Am. J. Physiol., 1947, 148, 597.

8. Bollman, J. L., and Mann, F. C., The physiology of the impaired liver. Ergebn. d. Physiol., 1936, 38, 445.

9. Reinecke, R. M., and Roberts, S., The effect of fasting on the blood sugar curve of the eviscerated rat. Am. J. Physiol., 1944, 141, 476.

10. Lundbaek, K., and Stevenson, J. A. F., Reduced carbohydrate intake after fat feeding in normal rats and rats with hypothalamic hyperphagia. Am. J. Physiol., 1947, 151, 530.

11. Best, C. H., Haist, R. E., and Ridout, J. H., Diet and the insulin content of pancreas. J. Physiol., 1939, 97, 107.

12. Himsworth, H. P., Dietetic factors influencing the glucose tolerance and the activity of insulin. $\mathrm{J}$. Physiol., 1934, 81, 29.

13. Lundbaek, K., and Goranson, E. S., The effect of fasting on muscle phosphorylase activity in the rat. Acta physiol. Scandinav., 1949, 17, 280.

14. Lundbaek, K., Metabolic abnormalities in starvation diabetes. Yale J. Biol. \& Med., 1948, 20, 533.

15. Natelson, S., Pincus, J. B., and Lugovoy, J. K., Response of citric acid levels to oral administration of glucose. I. Normal adults and children. J. Clin. Invest., 1948, 27, 446.

16. Mårtensson, J., On the citric acid metabolism in mammals. Acta physiol. Scandinav., 1940, 1, Suppl. 2.

17. Pincus, J. B., Natelson, S., and Lugovoy, J. K., Response of citric acid levels of normal adults and children to intramuscular injection of epinephrine. J. Clin. Invest., 1949, 28, 741.

18. Östberg, O., The citric acid content of urine in alkalosis and acidosis. Biochem. Ztschr., 1930, 226, 162.

19. Fürth, O., Minnibeck, H., and Edel, E., The role of citric acid in carbohydrate metabolism. Biochem. Ztschr., 1934, 269, 379.

20. Kuyper, A. C., and Matill, H. A., Some aspects of citric acid metabolism. J. Biol. Chem., 1933, 103, 51.

21. Lenner, A., Uber Zitronensäurebestimmungen und das Vorkommen der Zitronensäure im menschlichen Körper. Acta obst. et gynec. Scandinav., 1934, 14, Suppl. 1. 